Srinivasan, R. (2020). Good Intentions. The Cambridge Journal of Postcolonial Literary Inquiry, 7(2), 203-209. doi:10.1017/pli.2019.37

\title{
Good Intentions
}

Ragini Tharoor Srinivasan

Ragini Tharoor Srinivasan teaches English and Social, Cultural, and Critical Theory at the University of Arizona. A former magazine editor and award-winning essayist, she has published in over three dozen scholarly, journalistic, and semi-public outlets. Recent essays discuss contemporary South Asian Anglophone and Asian/American literatures, critical amateurism, the careers of canonical feminist texts, and the renomination of the postcolonial as world Anglophone. (Email: rtsrinivasan@email.arizona.edu)

Keywords: documentary, photography, humanitarianism, voice, subaltern

\begin{abstract}
This article is part of a special forum on Pooja Rangan's award-winning monograph Immediations: The Humanitarian Impulse in Documentary (Duke University Press, 2017)
\end{abstract}

In late June 2019, news outlets around the world published journalist Julia Le Duc's photograph of the bodies of Óscar Alberto Martínez Ramírez and his twenty-threemonth-old daughter, Valeria, who drowned in the Rio Grande while attempting to migrate to the United States. The photo depicts the two facedown in the water, inert limbs embracing. Valeria is entangled in her father's black t-shirt; she wears sneakers and fire- 
engine red shorts. The blue of Ramírez's shorts matches the cans of Bud Light strewn around the riverbank and around their bodies.

It is a devastating image, and for a news cycle or two, it took the air out of badfaith debates on the rights of migrants and asylum seekers in the United States. "It's our version of the Syrian photograph —of the three-year-old boy on the beach, dead. That's what it is," said Texas Congressman Joaquin Castro, referring to the 2015 photo of the body of Alan Kurdi, who drowned in the Mediterranean Sea while his family was trying to reach the Greek island of Kos. ${ }^{1}$ Kurdi's photograph, taken by Nilüfer Demir, has been credited with compelling European governments "to open closed frontiers." Castro hoped that Le Duc's photograph would communicate the urgency of the humanitarian crisis on the US-Mexico border and galvanize an immediate political response.

Soon enough, however, the image was folded into the ongoing daily reports of family separations, ICE-led round-ups of undocumented US residents, and concentration camps masquerading as border patrol facilities. The American public moved on, as if unmoved, however moved we thought we had been. Óscar Ramírez and Valeria's dreams and struggles, their lives, had not been enough to secure their futures. Their deaths were equally inadequate to the task.

I've been wanting to ask Pooja Rangan about these images and these deaths, about Valeria Ramírez and Alan Kurdi. Might their photographic capture represent the ghastly consummation of the humanitarian impulse that Rangan so brilliantly deconstructs in Immediations: The Humanitarian Impulse in Documentary? If documentary films require that their subjects live (the Foucaultian phrasing is deliberate and accords with Rangan's argument) so as to sound their voices, reveal their selves, and 
display their humanity, then doesn't the silenced, dead subject—-the body in the rushes amid the beer cans - serve as every such film's unseen final frame, the spectral engine of humanitarian interference, the ghostly epilogue that hangs like a threat over every shot?

Or have I got that twisted? Construed more generously, can the humanitarian documentary be understood as a response to the failure of the image? (Notwithstanding the initial reaction to Demir's photo, the Syrian refugee crisis continues at the time of this writing in summer 2019.) Reflecting on the "too easy" way in which photographs like Valeria Ramírez's and Alan Kurdi’s are at once remembered and forgotten, Teju Cole asks, "Who are we if we need to look at ever more brutal images in order to feel something? What will be brutal enough?"’3 Maybe contemporary documentary filmmakers take up the interventionist charge specifically because no image has been "brutal" enough to move us to our collective senses, because of the photograph's impotence, because what Susan Sontag calls the "ceaseless flow" of horrific photos of tragedies has only supplied viewers with "the bemused awareness ... that terrible things happen. ${ }^{44}$ Regarding the pictured pain of others has rarely been enough to put an end to their pain, so filmmakers try to amplify their voices, make resonant their interiority, let them display their fully human selves_-before their bodies wash up on the riverbank.

This is not a defense of documentary humanitarianism, not yet anyway. Having been thoroughly convinced by Rangan that participatory documentary motivated by humanitarianism is "a regulatory capture apparatus," $\mathrm{I}$ 'm just trying to remind myself why filmmakers pursue endangered Others in the first place. Within every touristic, benevolent, prurient humanitarian documentary is a sticky morass of good intentions, activist hopes, and artistic dreams. Can we read them? Do they matter? If a film "does" 
good but fails its subjects, should that inflect our reading of its immediations? What about a film that fails to move audiences but tries to empower its subjects? These are undoubtedly the wrong questions to ask Rangan, as will be clear in what follows. I want to ask them anyway.

Immediations argues that endangered lives (Rangan's examples include the children of prostitutes, hurricane victims, the autistic, and rescued animals) supply socialjustice-oriented documentary films with their "raison d' être." The former serve the latter, not the other way around. This is especially true when filmmakers enlist threatened, disenfranchised, or otherwise precarious subjects as coproducers of their respective texts. Under Rangan's careful, charismatic scrutiny, all the stock, selfcongratulatory alibi of participatory documentary-we are giving a voice to the voiceless; we are putting faces to the faceless; we are returning to them their humanity; we are allowing audiences to see through their eyes instead of our own-fall apart. These are not magnanimous or self-abnegating directorial choices, Rangan shows, nor enlightened modes of empowering the Other. Rather, the "guiding humanitarian ethic [of] giving the camera to the other-invents the very disenfranchised humanity that it claims to redeem." ${ }^{\prime 7}$ In other words, giving the camera to the Other is not a gift. It is a discursive trap that presumes and necessitates a return performance of audible and legible humanity that, by design, only the filmmaker and film are able to identify, display, and recover.

Suffice it to say, this is not the conventional way that humanitarian documentaries are read. Consider the words that begin A.O. Scott's review of the Academy Awardwinning 2004 Born into Brothels, which documents the lives of children of Kolkata prostitutes and turns them into self-actualizing artistes in the process: "The impulse to 
document the lives of poor, neglected and oppressed people, which motivates countless filmmakers and photojournalists, is unquestionably noble." ${ }^{8}$ There's nothing noble about this impulse as Rangan reads it. Yes, the brothel children are given photography lessons, but they are also enlisted in the laborious documentation of their lives and worlds. Their photos feed, philosophically and materially, codirector and photojournalist Zana Briski's nonprofit organization, Kids with Cameras, as well as Briski's itineraries on the international film circuit. Born into Brothels, its boosters, and the related nonprofit all present the children's photographs as windows into their souls, as not only what they see and how they see but who they are. And yet, Rangan shows, the children were specifically taught to adopt a "photographic aesthetic of feral innocence" (imagine a photo of a Kolkata slum-kid jumping rope, one taken by her playmate) that bolstered Briski's humanitarian mandate by communicating their innocence and secured the marketability of their photographs on a global stage.

The aesthetic of childhood innocence is just one of the "audiovisual tropes" or "immediations" that Rangan identifies as frequently employed in documentaries operating "in the mode of emergency." ${ }^{10}$ Border crises, sex trafficking, ecological devastation, climate catastrophe, the AIDS epidemic, threat of nuclear fallout, animals on the verge of extinction, Zika, measles: such emergencies, even when contrived, require the suspension of our conventional modes of temporal inhabitance. They demand that we stop discussing solutions to problems and instead just $d o$, now. Correspondingly, documentary filmmakers use tropes such as televisual liveness and the first-person voiceover in order to arrest viewers' attentions and direct us toward immediate action. It's not hard to imagine how a "kids with cameras"-type project in a migrant detention center on 
the US-Mexico border would work today. Images of predatory guards, open sores on unwashed bodies, and miscarrying teenagers on blood-soaked cardboard would misfire, but photos of children improvising play with toilet paper rolls and Mylar blankets would confirm their creativity, resilience, and humanity. See, we have to get them out of there now!

Immediations have specific reality effects; they make the subjects in question appear authentic, present, natural, actual, real. Bodies, experiences, and voices materialize tantalizingly on the screen as if unvarnished and "beyond the control of mediation." ${ }^{11}$ But nothing is beyond mediation, and in fact it takes considerable artifice or "alchemy" 12 to present a subject as if engaged in an act of pure, artless self-revelation. I watched Born into Brothels when it first came out and remember chafing against scenes of another White tour guide with well-intentioned missionary zeal exposing for an international audience the lives of impoverished Indian children. I didn't yet have the critical vocabulary of immediations (Rangan's original coinage), so I racialized my critique of the film and wrongly attributed its faults to the neocolonial power dynamics on display. Rangan's postcolonial critique is more sophisticated. She uses Johannes Fabian's work on allochronism to connect the appeal to universal discourses of childhood innocence to "the temporal distancing"13 of autistic and animal modes of communication that are embodied and non-normatively relational. She also explains how enlisting the children in their own documentation becomes the authorizing condition of Briski's film. It shields her from scrutiny and disguises the film's artifice. We aren't representing the children, see, they are representing themselves! 
But it isn't their film, and to use Gayatri Chakravorty Spivak's well-known words, a "postrepresentationalist vocabulary hides an essentialist agenda." ${ }^{" 14}$ Like rescued elephants trained to paint self-portraits (the subject of chapter 4, the upshot being that we care more about animals if they have "human"-like selves), the brothel children are asked both to produce recognizable, marketable versions of themselves and to perform "affective, virtuosic, and creative modalities of labor that are not recognized or compensated as such." ${ }^{15}$ This argument also builds through chapter 2's discussion of participatory media in the aftermath of Hurricane Katrina. Reading the 2008 film Trouble the Water, which includes eyewitness footage from a Katrina survivor, Rangan lays bare the trap of participating in one's own supposedly empowering documentation. She calls it "the predatory cultural logic of disaster capitalism," by which "the most vulnerable social subjects . . . actively absorb professional risks as personal liabilities." ${ }^{.16}$ Send us your images; tweet us your pictures; email us your location; interview your neighbors; tell us your story; "The Times needs your voice." More than a decade after Katrina, this predatory, postrepresentationalist logic unites coverage from crises to cat videos. Corporate media profit daily from the work of citizen reporters, who risk their lives to "speak for themselves," to film their houses burning down, their possessions floating away, even their lovers being murdered, as in the case of Diamond Reynolds's cell phone live-stream of the 2016 shooting of Philando Castile.

To be clear, what's at stake for Rangan is not the fact of expropriated profit, but rather that the subjects in question, whether camera-wielding children or video-recording victims, are being interpellated as producers of a very specific (read: liberal, Western) mode of being human. This is the argument at the philosophical heart of Immediations- 
participatory documentary films are "regulating what does and does not count as human"17 — and it connects Born into Brothels and Trouble the Water to the films about animal self-portraiture and autism in the later chapters. Whose vision is on offer in these films? What self is captured in a self-portrait? How does documentary refashion the endangered subject as "a native informant of sorts"? ${ }^{18}$ When a film gives viewers access to the supposedly unmediated voice of the disenfranchised, who, really, is speaking?

There are only two explicit references to Spivak's "Can the Subaltern Speak?" in Immediations (for that matter, only two pages listed in the index under "postcolonialism and postcolonialist scholars"), but I read Rangan's monograph as an extended response to the canonical essay. As I take it, Rangan revises Spivak's titular provocation into something like, “Can the subaltern not speak?" Does she have the right to remain silent? Can she be left good and well alone? As Spivak herself memorably argued, it's no more virtuous to "let" or "make" the subaltern speak than it is to speak "for" her because we only ever hear what we want to hear, what we can already hear, what we are primed to hear. As Rangan puts it in her reading of Amanda Baggs's “In My Language” (2007), "The autistic voice cannot be heard, seen, or acknowledged until it begins to speak in a recognizable tongue." ${ }^{19}$ Documentaries that aim to give endangered subjects a "voice" refuse to hear the voices they already have; in attempting to translate the Other's humanity, they elide existing human worlds. This, Rangan argues following Rey Chow, is the violence of humanitarian documentary's intention to affirm: Here, you speak; tell us who you really are; let us hear your real, true voice; show us your world, but in language and images we already understand, please. Also: tell us who you are so that we 
know why we need to save you; show us your humanity so that we see why you deserve to live.

Let me pause to acknowledge and account for those italicized lines. I've been ventriloquizing the voice of participatory documentary (five times now, if you're keeping count) in response to a book that uncompromisingly skewers the ventriloquism of documentary. I've been writing in the voice of documentary—saying what participatory documentary thinks, assuming what participatory documentary means-because I'm trying to understand how Rangan understands intention. The voice of documentary that I am playing with cannibalizes and perverts the voices of others in its furtherance of a liberal, Western version of humanity. Does it mean to? Does it matter? Rangan demonstrates that "the documentary tropes of articulate speech pathologize" ${ }^{20}$ certain voices and communicative modes. Might it also be the case that certain of our critical habits compel our skepticism of the humanitarian impulse, thereby circumscribing our readings in such a way that we end up valorizing anything that resounds against a filmmaker's terrible, horrible, no good, very bad (good) intentions?

Throughout Immediations, Rangan is critical of the audiovisual tropes of spontaneity, contingency, liveness, and "real time", ${ }^{21}$ she demonstrates persuasively how films that purport to reveal unmediated encounters prey on viewers' well-documented biases toward "the spontaneous, the rough, the imperfect."22 But by the end of the book, Rangan is trying to recuperate the possibility of the "unexpected." She holds out hope that the camera can capture life as lived and not as "scripted spectacle." 23 The final claim of her conclusion is that documentary films, whatever their filmmaker's intentions, might still be able to access "the spontaneous moment of the encounter." 24 
But haven't we already established that spontaneity can be a trap? That it can be refashioned as liveness, authenticity, an immediation that contributes to an overfamiliar pedagogy of the human and the social? It seems to me that Rangan wants to retain the promise of good spontaneity against bad spontaneity. This is my crass phrasing, not hers, but there are traces of it earlier in the book. For example, in her reading of Born into Brothels, she argues both that Briski exploits the rhetorics of amateurism, innocence, and untutored genius (bad spontaneity) and that Briski avoids showing or accounting for the children's more risky, somber, and sexually provocative photographs (good spontaneity). The latter represent what it looks like for the brothel children to thwart the coercive mimetic imperative to perform as redeemable subjects of participatory documentary and instead "return the gift of the camera with images and sounds inscribed with a trace of themselves, and of their mode of being in the world." ${ }^{25}$

Rangan is drawing an important distinction. It's one thing to try to confer humanity on the Other by turning her into a subject you already recognize; it is another thing entirely to "allow the medium to be repurposed in unforeseeable ways." ${ }^{\text {26 }}$ But I'm not entirely satisfied by the Derridean language of the trace, nor with the suggestion that the operations of the camera can be repeated with a difference, thereby subverting the humanitarian filmmaker's intentions. If we judge a film's potential to "[open] up the horizons of humanity" ${ }^{27}$ on the basis of its subject-participants specifically not producing what the filmmaker intends, aren't we again overdetermining the content of their production, just in reverse? I'm puzzling over this tension (I hope I'm not manufacturing it) because I also discern in Rangan a desire for what Trinh T. Minh-ha long ago described as the necessary "demystification of intention in filmmaking." ${ }^{28}$ Yes to viewer 
involvement, active receipt, less stultification, and the kinds of critical readings that Rangan models in Immediations. No to benevolence and charity. No to remaking the Other in my image. No more mistaking the "first-person voice-over" for a subject's "inner voice. ${ }^{29}$ No more taking the subtitular translation at its word.

Like the brutal photograph before it, humanitarian documentaries neither give us the world nor save it. The world is ours; we are always already of it. What's the camera for then? Over and above deconstructing good intentions, Rangan's critique of the humanitarian impulse charts a course for documentary film to become "a noninterventionist mode of encountering the other. ${ }^{30}$ If we relinquish our desires for legibility, audibility, and selfhood, we might yet make of documentary something other than "a representation designed for interpretation by a human subject." ${ }^{" 31}$ Dead bodies in the reeds, though, or washed up on the shore. Is it any surprise that we want to go back in time to know them, that we refashion them in our images, that against the limited capacities of our eyes and ears, we imagine we can hear them speak? 
${ }^{1}$ Azam Ahmed and Kirk Semple, "Photo of Drowned Migrants Captures Pathos of Those Who Risk it All," New York Times, June 25, 2019. Accessed July 31, 2019.

https://www.nytimes.com/2019/06/25/us/father-daughter-border-drowning-picture-mexico.html.

2 “TIME 100 Photos: Alan Kurdi,” Time. Accessed July 31, 2019.

http://100photos.time.com/photos/nilufer-demir-alan-kurdi\#photograph.

${ }^{3}$ Teju Cole, “A Crime Scene at the Border,” New York Times, July 10, 2019. Accessed July 31, 2019. https://www.nytimes.com/2019/07/10/magazine/drowned-migrants-photo-us-mexico-border.html.

${ }^{4}$ Susan Sontag, Regarding the Pain of Others (New York: Picador, 2003), 13, 21.

${ }^{5}$ Pooja Rangan, Immediations: The Humanitarian Impulse in Documentary (Durham, NC: Duke University Press, 2017), 156.

${ }^{6}$ Rangan, Immediations, 1.

${ }^{7}$ Rangan, Immediations, 1.

${ }^{8}$ A. O. Scott, "Nurturing the Talents of Children in Calcutta," New York Times, December 8, 2004. Accessed July 31, 2019. https:/www.nytimes.com/2004/12/08/movies/nurturing-the-talents-ofchildren-in-calcutta.html.

${ }^{9}$ Rangan, Immediations, 37.

${ }^{10}$ Rangan, Immediations, 4.

${ }^{11}$ Rangan, Immediations, 73.

${ }^{12}$ Sontag, Regarding the Pain of Others, 81.

${ }^{13}$ Rangan, Immediations, 107.

${ }^{14}$ Gayatri Chakravorty Spivak, "Can the Subaltern Speak?” in Marxism and the Interpretation of Culture, eds. Cary Nelson and Lawrence Grossberg (Urbana: University of Illinois Press, 1988), 285.

${ }^{15}$ Rangan, Immediations, 28.

${ }^{16}$ Rangan, Immediations, 67.

${ }^{17}$ Rangan, Immediations, 8. 
${ }^{18}$ Rangan, Immediations, 113.

${ }^{19}$ Rangan, Immediations, 121.

${ }^{20}$ Rangan, Immediations, 21.

${ }^{21}$ Rangan, Immediations, 20.

${ }^{22}$ Sontag, Regarding the Pain of Others, 28.

${ }^{23}$ Rangan, Immediations, 196.

${ }^{24}$ Rangan, Immediations, 196.

${ }^{25}$ Rangan, Immediations, 194.

${ }^{26}$ Rangan, Immediations, 189.

${ }^{27}$ Rangan, Immediations, 15.

${ }^{28}$ Nancy Chen, “'Speaking Nearby’: A Conversation with Trinh T. Minh-ha,” Visual Anthropology

Review 8.1 (1992): 91.

${ }^{29}$ Rangan, Immediations, 117, 139.

${ }^{30}$ Rangan, Immediations, 17.

${ }^{31}$ Rangan, Immediations, 17. 